\title{
Influence of Copper and Metallic Alloys on the Oxidation Reaction of Commercial Biodiesel in Mixture with Natural Antioxidant
}

\author{
Letícia T. Chendynski, ${ }^{a}$ Érica S. Romagnoli, ${ }^{b}$ Ana Carolina G. Mantovani, ${ }^{c}$ \\ Marissa Kimura, ${ }^{b}$ Leonardo C. Marques ${ }^{a}$ and Dionisio Borsato ${ }^{\circledR} * b$ \\ IInstituto Federal do Paraná, R. João XXIII, 600, Judith, 86060-370 Londrina-PR, Brazil \\ ${ }^{b}$ Departamento de Química, Universidade Estadual de Londrina, \\ Rodovia Celso Garcia Cid, PR 445, km 380, 86057-970 Londrina-PR, Brazil \\ 'Departamento de Física, Universidade Estadual de Londrina, \\ Rodovia Celso Garcia Cid, PR 445, km 380, 86057-970 Londrina-PR, Brazil
}

\begin{abstract}
The purpose of this research was to evaluate the influence of metallic alloys and copper in the degradation of biodiesel in mixture with blackberry extract. Biodiesel is formed by unsaturated esters highly susceptible to the oxidation reaction. The initial induction period (IP) of the control sample was $9.53 \mathrm{~h}$ and, after 208 days, the IP reduced to $5.74 \mathrm{~h}$. However, with the addition of the antioxidant, the final IP was $6.27 \mathrm{~h}$. The assays involving carbon steel, stainless steel, silver steel and copper showed final IP of 3.78, 4.43, 1.59 and $0.09 \mathrm{~h}$, respectively. This behavior indicates that the reaction was catalyzed in the presence of metal. The addition of the blackberries extract favored the increase of the induction period and the decrease of the reaction rate constant values, aside from the carbon steel that presented a final IP of $1.22 \mathrm{~h}$. The highest rate constant was $7.41 \mathrm{~h}$ obtained for biodiesel in contact with copper, as well as the highest IP. The acid number ranged from 0.34 to $0.60 \mathrm{mg}_{\mathrm{KOH}} \mathrm{g}^{-1}$. It was possible to observe in the oxidation reactions the presence of the linearity deviation proposed by Arrhenius.
\end{abstract}

Keywords: biodiesel, storage stability, oxidation, metallic alloys, natural antioxidant

\section{Introduction}

Currently, among the renewable energies of interest are the biofuels. These materials are fuels derived from renewable raw materials. Biodiesel, ethanol and biogas are the most used, with ethanol being a substitute for gasoline, and biodiesel an alternative to petrodiesel. ${ }^{1}$

Biodiesel obtained from vegetable oils and animal fats are less stable compared with petrodiesel..$^{2,3}$ This biofuel has lower stability to oxidation because it has higher levels of unsaturated esters, especially polyunsaturated carbon chains, ${ }^{4-7}$ and there is the formation of different organic compounds such as organic acids, aldehydes, esters, ketones, alcohols and peroxides, increasing the acidity as the degradation progresses. ${ }^{8,9}$ The degradation of biodiesel during storage is caused by oxidation. The oxidation process can occur in contact with air, ultraviolet radiation, thermal decomposition, by hydrolysis in contact with water

*e-mail: dborsato@uel.br or moisture in storage containers and also it occurs due to biological or metallic contamination. ${ }^{10-14}$

Cazarolli et al..$^{15}$ cited that microbiological contamination compromises the quality of biodiesel. The results of fungal growth showed that stored biodiesel was susceptible to microbial degradation. Zimmer et al. ${ }^{16}$ cited that the use of biocides is effective in solving this storage problem.

Fazal et al. ${ }^{17}$ showed that biodiesel is more corrosive than diesel. This fact is crucial because of the transfer of metallic ions to biodiesel, compromising quality and oxidative stability. ${ }^{17,18}$ The metal contaminants can be derived from a variety of sources, such as the copper heat exchangers used in the production of biodiesel, ${ }^{19}$ the storage or transport containers where contamination occurs through direct contact with the surface of the container or even by metallic sediments of the oxidation process. ${ }^{10,11}$

As mentioned by Yaakob et al. ${ }^{20}$ some of the materials used in the manufacture of storage container can accelerate 
the oxidation of biodiesel and result in the formation of insoluble sediments. Kumar ${ }^{21}$ evaluated different aspects of biodiesel oxidation and affirmed that biodiesel in contact with metallic materials such as copper, zinc, lead, tin and brass, increases the rate of oxidative degradation catalyzed by metals. Only trace metals are sufficient for catalysis, whereas antioxidants inhibit or retard the oxidation reaction.

Recent researches showed that the use of natural and synthetic antioxidants reduces the rate constant of the oxidation reaction and, consequently, decreases the degradation. Plant extracts such as rosemary, oregano, basil, blackberries, hibiscus, sage, as well as agricultural residues as pistachio hull, contain phenolic compounds, behaving as antioxidants. ${ }^{18,22-24}$

In the structures of most antioxidants, there are aromatic rings or structures with double conjugated bonds that allow electronic delocalization. This fact produces radicals less reactive and prevents radical reaction. ${ }^{8}$ The hydroxyl group provide protons which inhibit the formation of free radicals or disrupt the propagation of these radicals by reducing the reaction rate. ${ }^{25,26}$

Thus, for the oxidation reaction to occur, it is necessary that the available energy reaches the activation energy (Ea). $\mathrm{Ea}$ is defined by the energy difference between the transition state and the reagents, with no dependence of the temperature. ${ }^{27}$ The study of the activation energy of the oxidation reaction promotes the understanding of how the degradation occurs and how to avoid it with the addition of antioxidants in order to increase the Ea. ${ }^{18,22}$ This concept is used only for elementary reactions and it does not fit for complex reactions. In some cases, there is a dependence on temperature. ${ }^{27-29}$ Thus, the concept of apparent activation energy (Eaa) was established, which shows that some temperature-dependent reactions can only be determined from the experimental data. ${ }^{27}$

The present research aims to evaluate the effect of metallic alloys and their metallic ions on the oxidation reaction of biodiesel in mixture with blackberries extract.

\section{Experimental}

\section{Biodiesel}

The company BS-BIOS (Marialva, Paraná) provided the biodiesel (B100) in agreement with ANP Technical Regulation No. $3 / 2014 .{ }^{30}$ Table 1 shows the specifications of the commercial biodiesel. The biodiesel used consists of approximately 60.8 and $39 \%$ of unsaturated and saturated esters, respectively. The iodine value result was 107.00 .

\section{Alcoholic extract preparation}

Blackberries were kiln dried at $60{ }^{\circ} \mathrm{C}$ for three days. They showed water content of $88.20 \%$. For $10 \mathrm{~g}$ of blackberries in natura, approximately $1 \mathrm{~g}$ of dried blackberries were obtained. The alcoholic extract of the natural antioxidant was produced according to the methodology described by Romagnoli et al. ${ }^{22}$ The total phenol compounds were determined by spectrophotometry according to the methodology described by Kumazawa et al. ${ }^{38}$ The total phenol content was of $17.7 \mathrm{mg}_{\mathrm{GAE}} \mathrm{g}^{-1}$ dry mass.

\section{Sample preparation and analyses}

Different commercial metal alloys were used to simulate the storage. For this study, samples of carbon steel (Carbon S.), silver steel (Silver S.), copper (Cu) and stainless steel 304 (Stainless S.) were utilized. The different metal alloys were cleaned with hexane to remove any residues. Also, it was performed a chemical stripping process in acid solution at $80{ }^{\circ} \mathrm{C}$ for the removal of oxides.

The mixtures (Table 2) containing $320 \mathrm{~g}$ of biodiesel, metal alloys with a surface area of approximately $52.5 \mathrm{~cm}^{2}$, blackberries extract and the control were placed in $500 \mathrm{~mL}$ beaker and stored at room temperature in the absence of light. The extract concentration of $0.8 \%(\mathrm{v} / \mathrm{v})$ was added in each sample, after the ethyl alcohol evaporation.

Table 1. Commercial biodiesel (B100) specifications

\begin{tabular}{lcccc}
\hline Parameter & Method & Specification & Unit & Result \\
\hline Density $\left(20^{\circ} \mathrm{C}\right)$ & ASTM D4052 & 850 to 900 & $\mathrm{~kg} \mathrm{~m}^{31}$ & 879.90 \\
Kinematic viscosity $\left(40^{\circ} \mathrm{C}\right)$ & ASTM D445 ${ }^{32}$ & 3.0 to 6.0 & $\mathrm{~mm}^{2} \mathrm{~s}^{-1}$ & 4.44 \\
Water content & ASTM D6304 ${ }^{33}$ & max. 200 & $\mathrm{mg} \mathrm{kg}^{-1}$ & 191.10 \\
Flash point & ASTM D93 & min. 100.0 & $\%$ mass & 151.50 \\
Ester content & EN $14103^{35}$ & 96.5 & $\%$ mass & 99.80 \\
Iodine value & EN $14111^{36}$ & - & hour & 107.00 \\
Induction period (IP) & EN $14112^{37}$ & min. $8 \mathrm{~h}$ & 9.50 \\
\hline
\end{tabular}


Table 2. Composition of the mixtures containing biodiesel (B100), metallic alloys and natural antioxidant (ant.)

\begin{tabular}{lccc}
\hline Assay & Composition & Assay & Composition \\
\hline 1 & B100 (control) & 6 & B100 + ant. \\
2 & B $100+$ Cu & 7 & B100 + Cu + ant. \\
3 & B100 + Silver S. & 8 & B100 + Silver S. + ant. \\
4 & B100 + Carbon S. & 9 & B100 + Carbon S. + ant. \\
5 & B100 + Stainless S. & 10 & B100 + Stainless S. + ant. \\
\hline
\end{tabular}

Silver S.: silver steel; Carbon S.: carbon steel; Stainless S.: stainless steel 304 .

The samples for each mixture were submitted to the accelerated heating at $110,115,120$ and $125^{\circ} \mathrm{C}$ using the Rancimat equipment (brand: Metrohm; model: 873), according to the methodology described in the standard EN14112. ${ }^{37}$ The acid number of the biodiesel were performed according to D664-11. ${ }^{39}$

$\mathrm{X}$-ray fluorescence technique analysis were conducted with Shimadzu 7000 energy dispersive X-ray spectroscopy (EDX). A calibration curve with concentrations of $\mathrm{Fe}^{3+}$ ions $\left(\mathrm{FeCl}_{3} \cdot 6 \mathrm{H}_{2} \mathrm{O}\right.$, Synth) of $2.0 \times 10^{-4}, 4.0 \times 10^{-4}$, $6.0 \times 10^{-4}, 8.0 \times 10^{-4} \mathrm{~mol} \mathrm{~L}^{-1}$ was performed. All analyzes were performed in triplicate. The analysis of the kinetic parameters and the apparent activation energy calculations (Eaa) were performed according to Chendynski et al. ${ }^{18}$

\section{Results and Discussion}

Table 3 shows the results of the biodiesel induction period (IP) analyzes during the period evaluated for the assays described in Table 2. The samples containing silver steel and copper are in the right part of Table 3 with different analysis intervals from the other samples because the degradation was fast.

The oxidation reaction in the presence of copper (assays 2 and 7) showed the lowest induction period values in a short period of time. This fact indicates that the reaction was catalyzed in contact of metal. The oxidative degradation occurred quickly in relation to the control sample, even with the addition of the blackberries extract in these assays. Among the metallic alloys used, the sample of silver steel is the one that caused the fastest degradation of biodiesel.

The results obtained are in accordance with the research done by Jain and Sharma, ${ }^{40}$ which evaluated the catalytic effect of copper, iron, nickel, manganese and cobalt ions on biodiesel produced with Jatropha curcas. The copper ions presented higher rate of catalysis, followed by cobalt, manganese, nickel and iron, whereas aluminum did not modify significantly the rate constant.

Sarin et al..$^{12,41}$ evaluated the degradation of biodiesel caused by metallic naphthenates of cobalt, manganese, iron, copper and nickel, simulating possible metallic contaminations. Among the salts listed, copper showed the highest rate of degradation, justified by its strong prooxidant effect. Knothe and Dunn ${ }^{13}$ also observed that the diameter of metallic copper particles influences biodiesel degradation.

The presence of blackberries extract (assay 2) delayed the oxidation reaction. The phenolic compounds present in the blackberries extract decrease the reaction rate, agreeing with recent researches. ${ }^{18,23}$ This behavior happens because molecules of phenolic compounds act as antioxidants, providing a radical hydrogen, restoring the fatty acid ester molecule. The radical of the antioxidant molecule formed does not propagate the reaction and the aromatic ring present in the phenolic compounds provides stability due to electronic delocalization.

Jacques and Zambiazi ${ }^{42}$ cite that the antioxidant action of blackberries extract is attributed to inhibition of oxidation by the presence of phenolic compounds, flavonoids as anthocyanins and other compounds such as

Table 3. Induction period (IP) at $110{ }^{\circ} \mathrm{C}$ during the storage period analyzed

\begin{tabular}{|c|c|c|c|c|c|c|c|c|c|c|c|c|}
\hline \multirow{2}{*}{$\begin{array}{l}\text { Period / } \\
\text { days }\end{array}$} & \multicolumn{6}{|c|}{ IP / h } & \multirow{2}{*}{$\begin{array}{c}\text { Period / } \\
\text { days }\end{array}$} & \multicolumn{2}{|c|}{$\mathrm{IP} / \mathrm{h}$} & \multirow{2}{*}{$\begin{array}{c}\text { Period / } \\
\text { days }\end{array}$} & \multicolumn{2}{|c|}{$\mathrm{IP} / \mathrm{h}$} \\
\hline & Control & $\mathrm{B} 100+$ ant. & Carbon S. & $\begin{array}{c}\text { Carbon S. + } \\
\text { ant. }\end{array}$ & Stainless S. & $\begin{array}{c}\text { Stainless S. } \\
+ \text { ant. }\end{array}$ & & Silver S. & $\begin{array}{c}\text { Silver S.+ } \\
\text { ant. }\end{array}$ & & $\mathrm{Cu}$ & $\mathrm{Cu}+$ ant \\
\hline 1 & 9.53 & 10.76 & 9.53 & 10.76 & 9.53 & 10.76 & 1 & 9.53 & 10.76 & 1 & 9.53 & 10.76 \\
\hline 48 & 8.94 & 10.27 & 7.47 & 4.90 & 7.34 & 9.06 & 48 & 3.12 & 3.92 & 2 & 0.09 & 4.71 \\
\hline 70 & 8.78 & 9.40 & 6.93 & 3.14 & 7.10 & 8.66 & 61 & 2.67 & 3.36 & 7 & - & 1.94 \\
\hline 100 & 8.35 & 9.70 & 6.28 & 2.49 & 6.69 & 8.17 & 70 & 2.46 & 2.83 & 14 & - & 1.68 \\
\hline 139 & 7.55 & 8.25 & 5.60 & 2.05 & 5.63 & 7.09 & 82 & 2.20 & 2.61 & 31 & - & 1.58 \\
\hline 180 & 6.48 & 6.99 & 4.43 & 1.67 & 4.95 & 5.74 & 100 & 1.90 & 2.16 & 38 & - & 1.53 \\
\hline 208 & 5.74 & 6.27 & 3.78 & 1.22 & 4.43 & 5.06 & 139 & 1.71 & 1.59 & 56 & - & 1.36 \\
\hline & & & & & & & & & & 95 & - & 0.56 \\
\hline
\end{tabular}

B100: biodiesel; ant.: antioxidant; Carbon S.: carbon steel; Stainless S.: stainless steel 304; Silver S.: silver steel. 
kampferol, quercetin, gallic acid, hydroxybenzoic acid, caffeic acid, coumaric acid, tocopherols (vitamin E), ascorbic acid and carotenoids.

It is possible to observe that, among the alloys used, stainless steel did not accelerate the degradation of biodiesel in comparison to the control sample. The stainless steel is one of the materials that is compatible with biodiesel, presenting no degradation in the biofuel, as mentioned by Yaakob et al. ${ }^{20}$ All the metal alloys used interact in different ways with the biodiesel sample, allowing catalysis of the oxidation reaction.

This biofuel, in contact with the carbon steel alloy, presented high induction periods when compared to the other samples. It is noted that biodiesel in the presence of the carbon steel and antioxidant provided a negative effect, degrading more rapidly than the assay containing only the carbon steel sample. One hypotheses for this behavior is the corrosion caused by the sedimentation of the particles present in the blackberries extract, because this assay, different from the other alloys, showed visible corrosion. For the determination of ions present in the biodiesel, an EDX analysis was performed according to the methodology.

Assay 9 with biodiesel and carbon steel with antioxidant extract presented a final concentration of iron ions of $2.7 \times 10^{-4} \mathrm{~mol} \mathrm{~L}^{-1}$. This fact indicates that a transfer of metallic ions from carbon steel to the biodiesel occurred. Also, there was an increase in the catalysis of the oxidation reaction. Therefore, the use of blackberries extract with this metal alloy is not recommended for biodiesel storage. None of the other samples have iron ions.
The oxidation reaction of biodiesel is of first order ${ }^{23}$ and the determination of all rate constants was performed as described in the methodology. Table 4 shows the rate constants (k) at $110{ }^{\circ} \mathrm{C}$ according to the metal alloy used and the storage period analyzed. The data from all the tests showed that the longer the storage period, the higher the rate constant (k). The reason for the reaction to occur more rapidly is due to the increase in the number of free radicals that propagate the reaction. ${ }^{18}$ It is also noted that in higher temperatures, there are the increase of the rate constants because more energy is supplied to the reaction system. The lower rate constants were observed in the stainless steel assays, when analyzed in the same storage period, and higher rate constants for samples containing copper.

Figure 1 shows the graphs of $\ln \mathrm{k}$ versus temperature $(\mathrm{T})^{-1}$ for the assays with deviations in the linearity of the Arrhenius equation showing the need of a second degree polynomial fit. The dashed line corresponds to the linear fit, the full line corresponds to the polynomial fit and the points represent the experimental data. This deviation can be sub or super-Arrhenius, depending on the behavior of the concave or convex curve, respectively. For the subArrhenius behavior, the activation energy increases with temperature increasing and, in the case of super-Arrhenius, it decreases with temperature increasing. ${ }^{27}$

It can be observed in Figure 1 that the assays with a nonlinear super-Arrhenius behavior are: the control sample at day 139 (Figure 1a); the assays with biodiesel and stainless steel at day 208 (Figure 1d); biodiesel and silver steel at

Table 4. The rate constants (k) in the respective days of storage at $110^{\circ} \mathrm{C}$

\begin{tabular}{|c|c|c|c|c|c|c|c|}
\hline \multirow{2}{*}{ Assay } & \multicolumn{7}{|c|}{ Days } \\
\hline & 48 & 70 & 100 & 139 & 180 & 208 & \\
\hline Control & 0.36 & 0.30 & 0.32 & 0.41 & 0.43 & 0.50 & \\
\hline $\mathrm{B} 100+$ ant. & 0.28 & 0.25 & 0.30 & 0.36 & 0.42 & 0.42 & \\
\hline Carbon S. & 0.40 & 0.35 & 0.46 & 0.46 & 0.63 & 0.69 & \\
\hline Carbon S. + ant. & 0.53 & 0.63 & 0.96 & 1.14 & 1.47 & 1.60 & \\
\hline Stainless S. & 0.18 & 0.33 & 0.44 & 0.49 & 0.60 & 0.65 & \\
\hline \multirow[t]{3}{*}{ Stainless S. + ant. } & 0.19 & 0.31 & 0.36 & 0.40 & 0.50 & 0.58 & \\
\hline & \multicolumn{7}{|c|}{ Days } \\
\hline & 48 & 61 & 70 & 82 & 100 & 139 & \\
\hline Silver S. & 1.05 & 1 & 1.10 & 1.58 & 1.60 & 1.21 & \\
\hline \multirow[t]{3}{*}{ Silver S. + ant. } & 0.67 & 0.72 & 0.75 & 1.69 & 1.11 & 1.86 & \\
\hline & \multicolumn{7}{|c|}{ Days } \\
\hline & 2 & 7 & 14 & 31 & 38 & 56 & 95 \\
\hline $\mathrm{Cu}$ & 7.41 & - & - & - & - & - & - \\
\hline $\mathrm{Cu}+$ ant & 0.48 & 1.27 & 1.15 & 1.53 & 1.23 & 1.78 & 2.30 \\
\hline
\end{tabular}

B100: biodiesel; ant.: antioxidant; Carbon S.: carbon steel; Stainless S.: stainless steel 304; Silver S.: silver steel. 

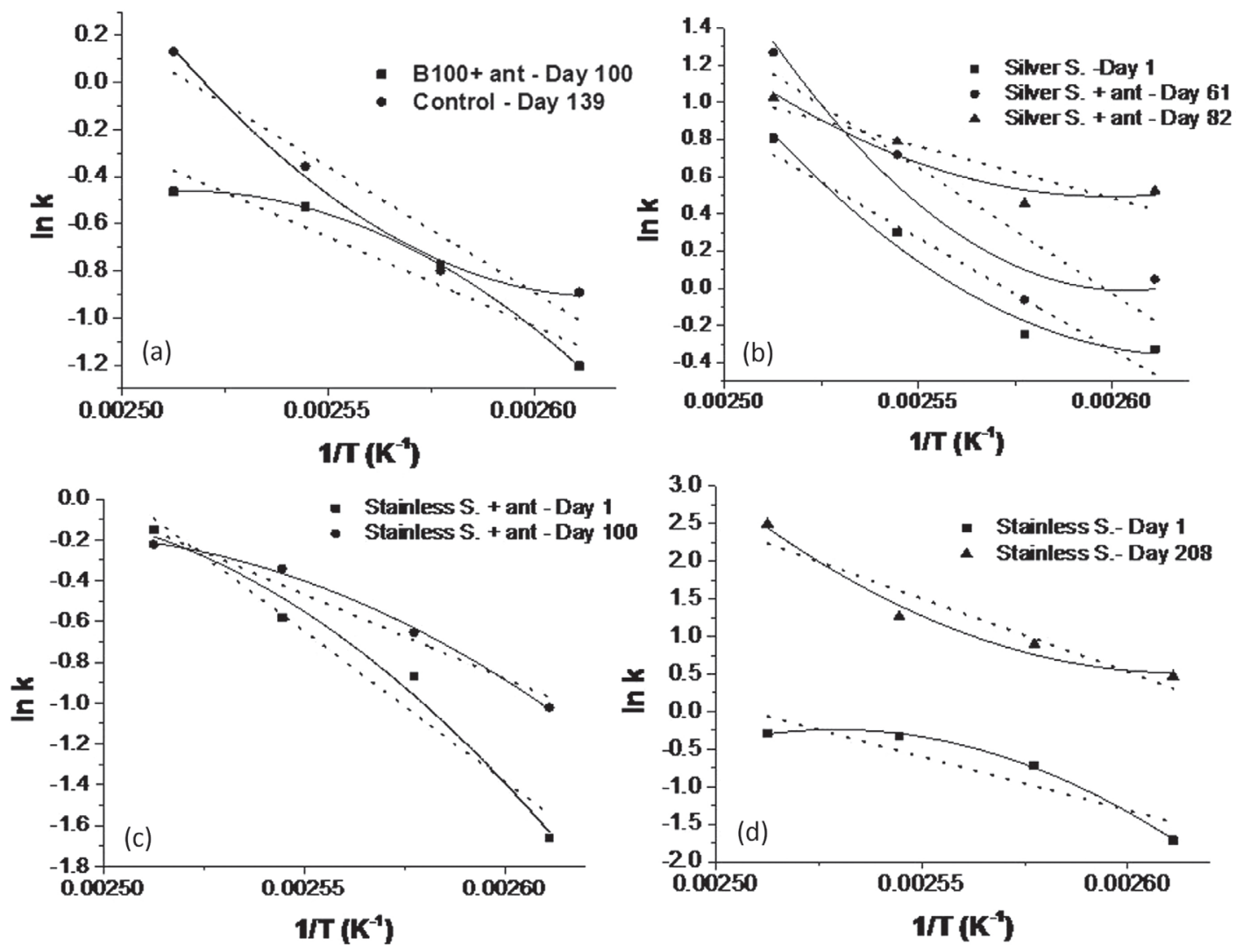

Figure 1. Deviations from the linearity in several samples in their respective days of analysis.

day 1 (Figure 1b); biodiesel with silver steel and antioxidant on days 61 and 82 (Figure 1b).

The sub-Arrhenius behavior was verified in the tests of biodiesel and antioxidant on day 100 (Figure 1a); stainless steel and antioxidant on days 1 and 100 (Figure 1c); and only biodiesel and stainless steel on day 1 (Figure 1d).

The second order polynomial fit provides an improvement in the determination coefficient $\left(\mathrm{R}^{2}\right)$ of the equations shown in Figure 1. In the other samples, there is an independence of the activation energy with the temperature.

Coutinho et al..$^{28}$ affirmed that processes exhibiting concave curvature in Arrhenius plots are related to the effects of quantum-mechanical tunneling, whereas convex curvature is typically a manifestation of contributions of classical phenomena.

Aquilanti et al..$^{43}$ describe that the super-Arrhenius behavior is manifested by the phenomena treated by the non-extensive thermodynamics of Tsallis. This model includes the particle diffusion and constraints on the proposed microscopic model, requiring that any successful approach to super-Arrhenius processes should be consistent with the microcanonical rate constant.

The behavior of the sub-Arrhenius type can be attributed in most cases to quantum mechanical tunneling in systems with no observable changes in the chemical mechanism. ${ }^{43}$

Hashemi et al ${ }^{44}$ cite that reactions with a high Ea are more sensitive to temperature variations. Therefore, the reaction temperature change has a significant effect on temperature-sensitive chemical reaction rates. Gregório et al. ${ }^{45}$ affirm that it cannot be considered for the oxidation reaction of biodiesel as just a simple relationship between the reagent and the temperature. This reaction is more complex and may present factors that favor it differently and independently of each temperature, modifying the predominant mechanism in each of them. ${ }^{45,46}$

The determination of the apparent activation energy of these samples is relevant to a better understanding of oxidative degradation in biodiesel, since there is an increase in the percentage of biodiesel added to diesel. With a higher commercial volume, a higher quality control requirement is required to meet the minimum of $8 \mathrm{~h}$ of induction period established by the Brazilian legislation. ${ }^{47}$

Table 5 presents the initial and final acidity of the assays performed. The increase of acidity is a consequence of the biodiesel oxidation reaction with the formation of alcohols, aldehydes, ketones, peroxides and low molecular weight acids, which are responsible for the alteration of the biodiesel properties. ${ }^{26}$ 
Table 5. Initial and final acidity of the samples in the analyzed period

\begin{tabular}{lcc}
\hline \multirow{2}{*}{ Assay } & \multicolumn{2}{c}{ Acid number $/\left(\mathrm{mg}_{\mathrm{KOH}} \mathrm{g}^{-1}\right)$} \\
\cline { 2 - 3 } Control & Initial & Final \\
B100 + ant. & 0.29 & 0.60 \\
$\mathrm{Cu}$ & 0.35 & 0.53 \\
$\mathrm{Cu}+$ ant. & 0.29 & 0.40 \\
Silver S. & 0.35 & 0.49 \\
Silver S. + ant. & 0.29 & 0.34 \\
Stainless S. & 0.35 & 0.47 \\
Stainless S. + ant. & 0.29 & 0.43 \\
Carbon S. & 0.35 & 0.48 \\
Carbon + ant. & 0.29 & 0.51 \\
\hline
\end{tabular}

B100: biodiesel; ant.: antioxidant; Silver S.: silver steel; Stainless S.: stainless steel 304; Carbon S.: carbon steel.

\section{Conclusions}

The initial IP of the control sample was $9.53 \mathrm{~h}$ and after 208 days, degradation reduced it to $5.74 \mathrm{~h}$. The addition of the antioxidant allowed a lower degradation and the biodiesel with blackberries extract presented a final IP of $6.27 \mathrm{~h}$. The assays involving carbon steel, stainless steel, silver steel and copper showed final IP of 3.78, 4.43, 1.59 and $0.09 \mathrm{~h}$, respectively. The addition of the blackberries extract favored the increase of the induction period and decrease of the values of the reaction rate constant, with the exception of carbon steel that presented a final IP of $1.22 \mathrm{~h}$. The highest rate constant was $7.41 \mathrm{~h}$ obtained for biodiesel in contact with copper. The acid number varied from 0.34 to $0.60 \mathrm{mg}_{\text {Кон }} \mathrm{g}^{-1}$ in the period evaluated for the different tests.

The oxidation of biodiesel in the presence of copper, with and without blackberries extract, showed the lowest values of induction periods and the highest rate constants, indicating the catalysis of the reaction in the presence of this metal. Therefore, due to the pro-oxidant effect of copper, this is the less indicated metal alloy in materials involved with production and storage of biodiesel.

The stainless steel sample was the alloy that less accelerated the degradation of biodiesel, followed by carbon steel, but this one presented unfavorable results in mixture with the blackberry extract. Different samples at different storage periods showed a deviation from the linearity proposed by Arrhenius and the determination of the apparent activation energy of these samples is relevant to a better understanding of the oxidative degradation in biodiesel.

\section{Acknowledgments}

The authors thank the State University of Londrina, Fuel Analysis and Research Laboratory and Federal Institute of Parana for support and infrastructure for the development of research.

\section{References}

1. Hassan, M. H.; Kalam, M. A.; Procedia Eng. 2013, 56, 39.

2. Chendynski, L. T.; Angilelli, K. G.; Ferreira, B. A. D.; Borsato, D.; Rev. Virtual Quim. 2016, 8, 823.

3. Knothe, G.; Fuel Process. Technol. 2005, 86, 1059.

4. Borsato, D.; Galvan, D.; Pereira, J. L.; Orives, J. R.; Angilelli, K. G.; Coppo, R. L.; J. Braz. Chem. Soc. 2014, 25, 1984.

5. Christensen, E. D.; Alleman, T.; McCormick, R. L.; Fuel Process. Technol. 2018, 177, 56.

6. Pölczmann, G.; Tóth, O.; Beck, Á.; Hancsók, J.; J. Clean. Prod. 2016, 111,85 .

7. Varatharajan, K.; Pushparani, D. S.; Renewable Sustainable Energy Rev. 2017, 82, 2017.

8. Sorate, K. A.; Bhale, P. V.; Renewable Sustainable Energy Rev. 2015, 41, 777.

9. Osawa, W. O.; Sahoo, P. K.; Onyari, J. M.; Mulaa, F. J.; Int. J. Energy Environ. Eng. 2016, 7, 85.

10. Comin, M.; de Souza, A. C. D.; Roveda, A. C.; Yahagi, S. S.; de Oliveira, L. H.; Amaral, M. S.; Silva, C. A. A.; Fiorucci, A. R.; Gomes, R. S.; Caires, A. R. L.; Fuel 2017, 191, 275.

11. Obadiah, A.; Kannan, R.; Ramasubbu, A.; Kumar, S. V.; Fuel Process. Technol. 2012, 99, 56.

12. Sarin, A.; Arora, R.; Singh, N. P.; Sarin, R.; Malhotra, R. K.; Energy Fuels 2010, 24, 2652.

13. Knothe, G.; Dunn, R. O.; J. Am. Oil Chem. Soc. 2003, 80, 1021.

14. Srivastava, S. P.; Hancsók, J.; Fuels and Fuel-Additives; John Wiley \& Sons, Inc.: New Jersey, 2014, p. 177.

15. Cazarolli, J. C.; de Quadros, P. D.; Bücker, F.; Santiago, M. R. F.; Piatnicki, C. M. S.; Peralba, M. C. R.; Cavalcanti, E. H. S.; Bento, F. M.; Biofuel Res. J. 2016, 3, 514.

16. Zimmer, A. R.; Oliboni, A.; Viscardi, S. L. C.; Teixeira, R. M.; Ferrão, M. F.; Bento, F. M.; Biofuel Res. J. 2017, 4, 627.

17. Fazal, M. A.; Jakeria, M. R.; Haseeb, A.; Rubaiee, S.; Energy 2017, 135, 220.

18. Chendynski, L. T.; Romagnoli, E. S.; da Silva, P. R. C.; Borsato, D.; Energy Fuels 2017, 31, 9613.

19. Mohammed, H. A.; Bhaskaran, G.; Shuaib, N. H.; Saidur, R.; Renewable Sustainable Energy Rev. 2011, 15, 1502.

20. Yaakob, Z.; Narayanan, B. N.; Padikkaparambil, S.; Unni, K. S.; Akbar, P. M.; Renewable Sustainable Energy Rev. 2014, 35 , 136.

21. Kumar, N.; Fuel 2017, 190, 328. 
22. Romagnoli, É. S.; Borsato, D.; Silva, L. R. C.; Tashima, D. L. M.; Canesin, E. A.; Biofuels 2017, DOI: 10.1080/17597269.2017.1418569.

23. Spacino, K. R.; Borsato, D.; Buosi, G. M.; Chendynski, L. T.; Fuel Process. Technol. 2015, 137, 366.

24. Ahanchi, M.; Tabatabaei, M.; Aghbashlo, M.; Rezaei, K.; Talebi, A. F.; Ghaffari, A.; Khoshnevisan, B.; Khounani, Z.; J. Clean. Prod. 2018, 185, 852.

25. Maia, E. C. R.; Borsato, D.; Moreira, I.; Spacino, K. R.; Rodrigues, P. R. P.; Gallina, A. L.; Fuel Process. Technol. 2011, 92, 1750 .

26. Karavalakis, G.; Hilari, D.; Givalou, L.; Karonis, D.; Stournas, S.; Energy 2011, 36, 369.

27. Aquilanti, V.; Mundim, K. C.; Elango, M.; Kleijn, S.; Kasai, T.; Chem. Phys. Lett. 2010, 498, 209.

28. Coutinho, N. D.; Silva, V. H. C.; de Oliveira, H. C. B.; Camargo, A. J.; Mundim, K. C.; Aquilanti, V.; J. Phys. Chem. Lett. 2015, 6,1553 .

29. Silva, V. H. C.; Aquilanti, V.; de Oliveira, H. C. B.; Mundim, K. C.; Chem. Phys. Lett. 2013, 590, 201.

30. Agência Nacional do Petróleo, Gás Natural e Biocombustíveis (ANP); Resolução ANP No. 45, de 25 Agosto de 2014; Diário Oficial da União: Brasília, 2014, Art. 1. Available at http:// legislacao.anp.gov.br/?path=legislacao-anp/resol-anp/2014/ agosto\&item=ranp-45--2014, accessed in August 2018.

31. ASTM D4052: Standard Test Method for Density, Relative Density, and API Gravity of Liquids by Digital Density Meter; ASTM International: West Conshohocken, PA, USA, 2002.

32. ASTM D445: Standard Test Method for Kinematic Viscosity of Transparent and Opaque Liquids (and Calculation of Dynamic Viscosity); ASTM International: West Conshohocken, PA, USA, 2007.

33. ASTM D6304: Standard Test Method for Determination of Water in Petroleum Products, Lubricating Oils, and Additives by Coulometric Karl Fischer Titration (Withdrawn 2016); ASTM International: West Conshohocken, PA, USA, 2004.

34. ASTM D93: Standard Test Methods for Flash Point by Pensky-Martens Closed Cup Tester; ASTM International: West Conshohocken, PA, USA, 2001.
35. EN 14103: Fat and Oil Derivatives. Fatty Acid Methyl Esters (FAME). Determination of Ester and Linolenic Acid Methyl Ester Contents; European Committee for Standardization: Brussels, 2003.

36. EN 14111: Fat and Oil Derivatives. Fatty Acid Methyl Esters (FAME). Determination of Iodine Value; European Committee for Standardization: Brussels, 2003.

37. EN 14112: Fat and Oil Derivatives. Fatty Acid Methyl Esters (FAME). Determination of Oxidation Stability (Accelerated Oxidation Test); European Committee for Standardization: Brussels, 2003.

38. Kumazawa, S.; Hamasaka, T.; Nakayama, T.; Food Chem. 2004, $84,329$.

39. ASTM D664: Standard Test Method for Acid Number of Petroleum Products by Potentiometric Titration; ASTM International: West Conshohocken, PA, USA, 2011.

40. Jain, S.; Sharma, M. P.; ISRN Renewable Energy 2012, 2012, article ID 861293.

41. Sarin, A.; Arora, R.; Singh, N. P.; Sarin, R.; Sharma, M.; Malhotra, R. K.; J. Am. Oil Chem. Soc. 2010, 87, 567.

42. Jacques, A. C.; Zambiazi, R. C.; Semina: Cienc. Agrar. 2011, $32,245$.

43. Aquilanti, V.; Coutinho, N. D.; Carvalho-Silva, V. H.; Philos. Trans. R. Soc., A 2017, 375, 20160201.

44. Hashemi, S. M. B.; Brewer, M. S.; Safari, J.; Nowroozi, M.; Abadi Sherahi, M. H.; Sadeghi, B.; Ghafoori, M.; Int. J. Food Prop. 2016, 19, 257.

45. Gregório, A. P. H.; Borsato, D.; Moreira, I.; Silva, E. T.; Romagnoli, É. S.; Spacino, K. R.; Biofuels 2017, DOI: 10.1080/17597269.2017.1332297.

46. Carvalho-Silva, V. H.; Aquilanti, V.; de Oliveira, H. C. B.; Mundim, K. C.; J. Comput. Chem. 2017, 38, 178.

47. Brasil, Lei No. 13.263, de 23 de Março de 2016 Altera a Lei No. 13.033, de 24 de Setembro de 2014, para Dispor sobre os Percentuais de Adição de Biodiesel ao Óleo Diesel Comercializado no Território Nacional; Diário Oficial da União: Brasília, 2016.

Submitted: June 19, 2018

Published online: August 17, 2018 